\title{
O TRIBUNAL REALISTA: CONSIDERAÇÕES CRÍTICAS SOBRE MACHADO DE ASSIS E O GÊNERO ROMANCE
}

\author{
Felipe Bier*
}

\begin{abstract}
Resumo
Este trabalho divide seus esforços críticos em dois flancos, tendo como fim tecer considerações acerca do romance enquanto gênero histórico. Primeiro tratar-se-á da relação entre ética, ideologia e representação literária a partir das considerações de Georg Lukács: a saber, será explorada a divisão histórica que serve de base para o pensamento do autor húngaro - cujo marco é o ano de 1848 - para sustentar a hipótese de que a conhecida crise da representação realista encontra raízes no nexo ideologia/forma literária. A segunda metade do trabalho evidenciará como tais questões encontram florescimento especial na obra de Machado de Assis: partindo de uma análise centrada em Dom Casmurro, trabalha-se com a hipótese de que a maneira peculiar de lidar com o tema da calúnia nesta obra oferece o vislumbre de outra relação entre forma literária e ideologia.
\end{abstract}

\section{Palavras-chave}

Calúnia, realismo, ética, ideologia, Machado de Assis.

\begin{abstract}
This work builds its theoretical efforts around a twofold reflection towards a view of the novel as a historical genre. Firstly we will work upon the relation between ethics, ideology and literary representation on the thought of Georg Lukács: the historical mark that grounds its considerations on the novel - namely the year of 1848 - will be explored in order to throw some light on the relations between the well known crises of literary representation and its nexus with the development of ideology within capitalist society. The second half of this work will show how these questions find a particularly rich ground to flourish on the work of Machado de Assis: having as center the novel Dom Casmurro, we will seek to show how the peculiar way in which the theme of calumny is treated on this piece of Brazilian literature offers a glimpse of the nexus between literary form and ideology.
\end{abstract}

\section{Keywords}

Calumny, realism, ethics, ideology, Machado de Assis.

* Doutorando no Programa de Pós-Graduação em Teoria Literária e Literatura Comparada na FFLCH -USP . E-mail: felipebier@gmail.com. 


\section{Kalumniator}

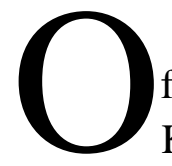

filósofo italiano Giorgio Agamben, ao comentar a obra de Franz

Kafka, lança uma interessante luz sobre a literatura enquanto forma ao chamar a atenção para um possível nexo entre a representação literária e o direito na obra do autor tcheco: diz o filósofo que, ao contrário do aporte difundido por intermédio de Max Brod, a insígnia $K$., que marca as protagonistas de $O$ castelo e $O$ processo, não faria referência ao sobrenome do escritor. Agamben aventa a possibilidade de esta escolha ter sido extraída dos estudos do antigo direito romano feitos por Kafka: diz o autor que, na antiga sociedade romana, "a calúnia representava para a administração da justiça uma ameaça tão grave, que o falso acusador era punido pela marcação na sua fronte da letra K (inicial de kalumniator)" (AGAMBEN, 2010, p.31, grifo no original). A hipótese de que as narrativas kafkianas revolvam em torno de uma reflexão acerca da calúnia é corroborada pela frase que abre o romance $O$ processo: "Alguém certamente havia caluniado Josef K., pois uma manhã ele foi detido sem ter feito mal algum" (KAFKA, 2005, p.7).

É possível que, para além de uma simples implicação na trama das obras kafkianas, a explicitação para o nexo entre calúnia e o labor literário, a partir da posição particular em que se coloca a personagem de $O$ processo - sujeito sobre o qual recaem os concomitantes atributos de caluniador e caluniado -, abra uma interessante perspectiva para o entendimento do próprio romance como gênero. Reclama-se assim a hipótese de que a forma específica do romance nasce às voltas com uma estratégia judicativa. Esta hipótese traz consigo outra proposição subterrânea: a de que, a contrapelo de certo consenso na crítica literária, o realismo não se constituiria como escola, mas como um arranjo formal que, premido por conjunturas históricas muito específicas, obrigaria a representação a lidar com um impasse que é gestado no ato de sua gênese enquanto gênero: a saber, o romance seria obrigado a conformar-se ao traço ético que o caracterizaria e que Georg Lukács chamou de ironia (cf. LUKÁCS, 2000, p.220). Seria precisamente no espaço da ironia - entre o compromisso com o real e sua pretensão universal -, ocupado primordialmente pelo narrador, que se armaria o tribunal no qual se desenrolariam os processos de calúnia e autocalúnia do romance burguês.

\section{Ideologia e forma}

A fundamentação histórica do argumento de Georg Lukács acerca do nascimento do gênero romance enquanto forma tem como pressuposto básico a perscruta dos eventos históricos que tiveram lugar na França a partir de 1789. A base de sua premissa reside na relação que se estabelece entre as drásticas mudanças sociais, que encontraram gatilho na revolução francesa, e a maneira como os homens perceberam sua atuação neste processo. A saber: argumenta Lukács que a rapidez das reviravoltas históricas impossibilitou que estas fossem percebidas como mudanças 
naturais. Assim, no ponto de dobradiça da catástrofe política, foi possível a cristalização de um "sentimento histórico" que impregna aquilo que o autor chama de fase clássica do romance, compreendida entre 1815 e 1848 (cf. LUKÁCS, 2011, p.18). Em resumo, o que se poderia afirmar acerca das consequências únicas à representação romanesca seria que, para Lukács, um ponto de reviravolta histórica sobre o qual incide uma verdadeira consciência subjetiva - isto é, do homem enquanto protagonista da história - imbui os ideais secretados pela ascensão da burguesia ao poder de caráter realista e abrangente. Neste contexto, o narrador do romance histórico, tal qual visto pelo crítico húngaro, alcançaria a façanha de plasmar em seu próprio gesto de formação subjetiva a consubstancialização do particular com o universal: isto é, movendo-se no interior da ideologia burguesa em expansão, o narrador faria de seu labor irônico o tecido que coligaria a subjetividade narrativa ao retrato histórico.

Assim se reclama uma relação fundamental entre uma teoria do sujeito que nasce junto ao romance e uma teoria ética da modernidade. Esta hipótese almeja englobar uma constatação já muito repisada: a de que o romance burguês dá lugar à atuação do sujeito autônomo que se forma, atua e intervém no mundo em movimento à sua volta. Haveria, no entanto, ainda uma importante afirmação acerca do sujeito romanesco que diz respeito ao âmbito mais profundo de sua forma: acredita-se que a relação fundamental entre ética e subjetividade, elevada às últimas consequências no romance burguês, esteja nas mãos do narrador e de sua atuação. É ao narrador que é legado o fardo de lidar com a dissonância necessariamente gerada pela fricção entre uma forma totalizante e o real.

A junção destes fatores fornece o rascunho daquilo que se pode chamar de célula básica da forma romanesca: uma forma que tem um compromisso com a representação séria do real, na qual se desenrola uma ação fortemente ancorada em solo histórico, e na qual é necessária a intervenção judicante do narrador, que assume e encarna a perspectiva moral que dá sustentação à ironia do romance. Diante deste quadro seria possível dar interessantes contornos à seguinte caracterização de Lukács do que o autor entende como a fase áurea do romance: "As crises históricas figuradas são componentes imediatos dos destinos individuais das personagens principais e constituem, assim, parte orgânica da própria ação. Desse modo, os elementos individual e sócio-histórico estão inseparavelmente ligados um ao outro tanto na caracterização quanto na condução do enredo" (LUKÁCS, 2011, p.246, grifos meus). Para que se possa dar pleno significado à organicidade da ação e, sobretudo, ao difícil ajuste entre "elementos individual e sócio-histórico" no romance pré-1848, é preciso que se tenha em mente a atuação de narradores como os presentes nos romances de Balzac, tidos em grande conta pelo crítico húngaro: trata-se de um narrador que interfere e que, mostrando sua face subjetiva, julga e tece comentários a respeito das personagens e da ação romanesca.

A organicidade a que se refere Lukács, portanto, pode ser traduzida por uma ironia orgânica, um ajuste irônico entre forma e real sustentado por um narrador subjetivamente seguro para exercer sua função judicante. Talvez seja neste sentido que se possa compreender a imanência lukacsiana, plasmada em seu conceito de gesto: a imanência do gesto narrativo, no qual a ação individual do protagonista enreda-se sem 
qualquer latência no enredo de fundo histórico, só é possível em um contexto em que o juízo do narrador acontece do interior da própria ideologia.

Esta interpretação é corroborada por uma afirmação do jovem Lukács em $A$ teoria do romance:

Pois o sujeito é constitutivo só quando age de dentro, apenas e tão somente o sujeito ético; ele logra esquivar-se à lei e ao estado de ânimo somente quando o palco de seus atos, o objeto normativo de sua ação, é formado com a matéria da pura ética: quando direito e costumes são idênticos à eticidade.

(LUKÁCS, 2000, p.66, grifos meus)

O autor húngaro não hesita em deixar claro quais são os pesos da balança que ele mobiliza: de um lado está a ação subjetiva imanente à ética - a ação "de dentro" -, de outro está a ação do sujeito moral - que age "de fora" e portanto em conluio com a lei. Tendo em vista os elementos postos em relação até aqui, é possível dizer que, dentro de tal perspectiva, o sujeito a que se refere Lukács no escrito de sua juventude será aquele que constituirá a face subjetiva do narrador do romance burguês: isto é, trata-se da instância que mantém coesa sua forma através de uma ironia sustentada de forma imanentemente ideológica. Como se disse, o movimento conceitual do autor húngaro é muito claro: em $O$ romance histórico, Lukács carrega de eticidade a forma romanesca em seu momento de apogeu ideológico; legando assim à forma da segunda metade do século o estigma de decaída por estabelecer uma relação moralmente irônica.

Em termos lukacsianos seria possível, portanto, caracterizar o romance anterior a 1848 como aquele em que uma ironia orgânica se desprende como subproduto da atuação do narrador, que faz de cada ato judicante uma diferenciação do interior do continuиm entre sujeito e ideologia. O gesto narrativo, neste contexto, encontraria respaldo na ideologia expansiva da burguesia do período revolucionário, e curiosamente faria coincidir a saga de seu herói romanesco com sua própria saga de classe: isto é, até a turbulência revolucionária de 1848, tal qual o narrador e o herói do romance moderno, a burguesia mesma via seus gestos reverberarem de maneira imanente na ideologia que secretava. Ou seja, é possível afirmar que, sem dúvida, como aponta Lukács, as bandeiras ideológicas burguesas verdadeiramente puderam ser consideradas como "bastiões do progresso": não à toa, afiança o autor húngaro, o hegelianismo e, posteriormente, o próprio marxismo nasceram deste solo.

O próximo passo deste exame será precisamente analisar quais as consequências para a representação literária realista advindas dos abalos de 1848 . Como se conformaria o arranjo entre universalismo e real quando o gesto que percorre este abismo deixa de encontrar respaldo imanente na ideologia burguesa? Colocado ante este dilema, o narrador do romance pós-1848 parece fazer eco à famosa frase de Marx ${ }^{1}$

Faz-se referência ao trecho de abertura de "O 18 Brumário de Luís Bonaparte": "Hegel observa em uma de suas obras que todos os fatos e personagens de grande importância na história do mundo ocorrem, por assim dizer, duas vezes. E esqueceu-se de acrescentar: a primeira vez como tragédia, a segunda como farsa" (MARX, 1997, p.21). Seria possível afirmar que toda a riqueza da análise marxista dos eventos políticos de 1848 na França pode ser extraída desta potente fórmula, sobretudo no que diz respeito à relação entre ideologia e reviravoltas políticas. 
ao sentir sua atuação tomar os ares de farsa: neste sentido, o caráter inquietante da intromissão narrativa na forma realista deve ser encarado ante os pontos de reviravolta na forma geral de representação da época, nos quais a ironia formal passa a carregar uma evidente carga de cinismo de classe. A saber: é preciso que se olhe atentamente para os deslocamentos operados no interior da forma-romance, sendo talvez o principal deles o da ironia, que deixa os ombros do sujeito-narrador e passa a operar seus gestos judicantes do interior da forma. Neste sentido se pode dizer que a literatura pós-1848 é uma literatura autocaluniosa: como que consciente da farsa alojada dentro desta instância irônica, a alta literatura burguesa deve se haver com a acusação que faz a si mesma. Qual seja: a de que obra um conluio com uma ideologia que, diante dos próprios frutos de seu progresso, já assumira seu caráter classista. Diante deste quadro o narrador judicante parece carregar uma ironia insuportável, um cinismo de classe pesado demais para a arte que almeja fugir de sua relação com a lei. Este é o tribunal que a literatura arma contra si própria.

\section{The figure in the carpet}

O conto de Henry James, publicado em 1896, "The figure in the carpet" fornece uma interessante imagem para que se pensem os percursos da composição realista da segunda metade do século. O mistério em torno do qual gira a trama - a saber, o segredo de composição da obra do consagrado autor Hugh Vereker - é iluminado de forma oblíqua pela metáfora que dá nome ao texto de James: o local de onde o narrador realista labora a ironia do romance assume ares de mistério precisamente por ocupar uma posição paradoxal, de uma absoluta exposição oculta: algo que, qual uma figura em um tapete persa, participa de sua composição ao mesmo tempo em que lhe dá forma.

Esta definição reclama um parentesco com o exame que fará Auerbach a respeito da representação realista pós-1848. Diz o crítico como preâmbulo à análise de Madame Bovary: "Na geração seguinte (à de Stendhal e Balzac), que faz sua aparição nos anos cinquenta, apresenta-se, neste sentido, uma violenta reação: com Flaubert o realismo torna-se apartidário, impessoal e objetivo" (AUERBACH, 2007, p.432). Esta constatação muitas vezes torna-se termo de acusação, como certamente é o caso do juízo de Lukács acerca da literatura realista da segunda metade do século XIX. Mas, ao se posicionar a objetividade almejada por autores como Flaubert no interior de uma história das formas literárias, é possível acessar o lastro histórico que subsidia este investimento na pretensa neutralidade realista. Com efeito, o jogo de cena perpetrado pelo realismo da segunda metade do século parece encontrar motivação em uma busca por um deslocamento da imanência no trato da ironia do romance: da imanência judicativa do narrador do romance histórico passa-se ao ajuste irônico sem suporte subjetivo, habitando o interior de estratégias formais.

Haveria, portanto, um "mistério" ou um "truque" por trás da pretensa objetividade do gesto descritivo e neutro do narrador pós-1848: é o que evidencia 
Auerbach ao comentar a passagem de Madame Bovary na qual se relata uma refeição entre Emma e o marido:

A própria passagem mostra um quadro: marido e mulher juntos, durante uma refeição. Mas este quadro não é mostrado, de forma alguma, em si ou por si mesmo, mas está subordinado ao objeto dominante, ao desespero de Emma. Por isso mesmo, também, não é apresentado ao leitor de forma imediata - eis duas pessoas sentadas à mesa, e lá está o leitor que as observa -, mas o leitor vê, em primeiro lugar, Emma, da qual muito se falou nas páginas anteriores, e somente através dela é que vê o quadro. De forma imediata, o leitor vê apenas o estado interno de Emma, e de forma mediata, a partir deste estado, à luz de sua sensação, vê o processo da refeição à mesa

(AUERBACH, 2007, p.433, grifo meu).

Vê-se, à luz deste comentário, como a mimese do objeto narrado - a cena de refeição de um casal pequeno burguês - se submete à perspectiva de um dado dominante que, de fato, concentra os sentidos da narração: o desespero de Emma. Desta forma, é possível dizer que o elemento mimético, naquilo que pode ser considerado o ponto alto da representação realista, não surge somente como dispositivo que obra a triangulação entre a palavra e o real, ou seja, como operador de mera descrição. $\mathrm{O}$ acesso ao real, neste caso, não abdica do elemento moral que, de forma tão visível, lidava com a ironia do romance da geração anterior à de Flaubert. Este mesmo elemento moral é aquele que arma um tribunal imanente ao texto: qual a figura no tapete, o desespero de Emma habita o fio mesmo da narração. Cada palavra do romance, neste sentido, sustenta o ajuste entre a forma universal e a vida a ser acessada pela representação a partir da paradoxal estratégia de autoaniquilamento da instância julgadora: ou seja, o grande efeito do texto está precisamente em seu truque autocalunioso, que, ao acusar-se, revela, por trás da neutralidade, sua inclinação moral.

Isto mostra o solo aporético sobre o qual se instala o narrador realista: do romance que surge após os graves abalos de 1848, todo o teor de realidade é retirado do narrador judicante: este passa a subsistir enquanto um espantalho do que fora, ou como um declarado agente do cinismo burguês ${ }^{2}$. Como se vê, os ajustes entre a forma universal e a matéria narrada perdem o suporte de uma subjetividade que, do interior da ideologia, pode sustentar o caráter universal da representação. Após o entrincheiramento desta mesma ideologia pós-1848, o próprio ataque à posição desta figura passa a se configurar como o tribunal judicante da representação. Neste sentido se, de fato, a ideologia burguesa perde seu caráter progressista, obrigando-se a atuar de "fora de si", isto é, a partir de sua própria alienação e enquanto ideologia moral e normativa, todo gesto irônico assume os tons de uma acusação. Ou seja, trata-se de um quadro de encruzilhada para o romance burguês: manter o narrador judicante significaria o mesmo que fazer de todo e qualquer ajuste irônico do romance um ponto de conivência com domínio de classe; a saída para este impasse deve atravessar, portanto, a difícil seara da autocalúnia. Aqui se entende a visão nostálgica de Lukács quanto ao romance pré-1848:

2 Ter em conta esta rotação de perspectiva no interior da ideologia burguesa talvez seja a melhor maneira de se compreender o caráter declaradamente moral dos romances de folhetim e, consequentemente, a reação que incitam na alta literatura realista. 
tratava-se de um contexto em que o gesto narrativo não se havia alienado e, por conseguinte, não havia sido posto em causa. Dito de outra forma, é possível traçar de fato, em linhas lukacsianas, o momento em que o narrador sai da ética para entrar na lei: ao perder seu caráter insuspeitamente universal, seguro pela ideologia burguesa, a posição do narrador precisa ser levada em conta, ou precisa ser objetivada para ser contornada ${ }^{3}$.

Como se disse, sair da ética para entrar na lei significa tão somente fazer de um gesto narrativo imanente à ideologia um gesto acusatório. Isto porque, como aponta Giorgio Agamben, é a acusação

a 'categoria' jurídica por excelência (...), aquela sem a qual todo o edifício do direito faltaria: o pôr em causa do ser no direito. Ou seja, o direito é, na sua essência, acusação, 'categoria'. E o ser posto em causa, 'acusado' no direito, perde sua inocência, torna-se 'coisa', isto é, causa, objeto de litígio (para os romanos, causa, res e lis eram, neste sentido, sinônimos)

(AGAMBEN, 2010, p.34, grifos no original)

Na medida em que o narrador, enquanto instância judicante, é ele mesmo posto sub judice, arma-se o ponto de saturação necessário para que a literatura revolva-se em torno de uma autocalúnia e entre definitivamente em uma via contraditória que, de modo geral, caracterizará toda a arte a partir da segunda metade do século XIX. Trata-se de um esforço na direção de atenuar, disfarçar, transformar ou mesmo eliminar o sujeito que narra: aporeticamente, longe de extirpá-lo, o conluio com a lei sugere uma estratégia de acesso ao real que se submete a esta tática autoacusatória. Assim, é possível dizer que um novo realismo surge como consequência direta do primeiro. Com efeito, de maneira alguma se pode erguer uma barreira entre o primeiro romance burguês e seus desdobramentos. Se a contradição histórica que acompanha a ascensão da burguesia culmina na carnificina de 1848, por que a mesma contradição não habitaria sua forma artística por excelência? Isto é, por que o heroísmo burguês não seria uma forma fadada à sua transformação em cinismo?

A grande questão que se erige neste ponto é, portanto, qual é este tipo de realismo que se configura como reação e, talvez mais precisamente, autoacusação do sujeito que se forma à sombra do narrador? Se se forjou no romance burguês o espectro de um sujeito que labora nos bastidores da representação, a saber, um sujeito que trabalha tecendo a mimese realista em torno da dissonância entre ideologia e a realidade, esta forma de atuação subjetiva é posta em cheque após os acontecimentos de 1848. Haveria, verdadeiramente, uma rotação de perspectiva na ironia romanesca, que deixa de ser imanente à voz do sujeito-narrador e se imiscui no interior das engrenagens formais do romance.

Esta segunda maneira de narrar - que se pergunta a todo momento "qual é a autenticidade e o lugar da voz que narra?" - impõe uma forma de realismo que,

3 Não é à toa, portanto, que grandes escritores desenvolvam, a partir deste momento, atividades críticas que necessariamente levam em consideração a discussão acerca da posição e atuação do narrador no romance realista, como é caso tanto de Henry James como de Machado de Assis. 
embrenhando-se no vão aberto na própria ideologia dominante, faz da autocalúnia um gesto de aproximação da vida. Para tornar mais palpável o argumento, é proveitoso voltar ao exame de Auerbach acerca de Flaubert: aquilo que é apresentado imediatamente e emerge absolutamente ao primeiro plano não são os detalhes descritivos da cena de refeição dos Bovary. O desespero de Emma, neste contexto, pode ser considerado o fruto deste complexo esquema narrativo que se tem tentado evidenciar: ele é, de fato, o efeito realista que o romance proporciona. Isto é, o efeito de real provém precisamente da exposição imediata daquilo que, na modernidade, torna-se mediato: o desespero pequeno-burguês de Emma, sua vida ressacada pela existência mesquinha, nada mais é do que o ponto de desenvolvimento capitalista em que a vida se transforma em mercadoria, tornando os ideais burgueses progressistas em elementos de uma farsa ideológica. Se necessário fosse exprimir este mecanismo narrativo em uma fórmula imperativa, ela seria: fazer a representação atravessar o ponto de alienação acusando-se-a de conluio com este processo. A possibilidade de esta fórmula existir se dá precisamente pelo ataque à instância que, ao mesmo tempo em que sustenta o romance, corrobora com sua estrutura normativa, uma vez que apoia a ironia romanesca. Ou seja, através da autoacusação do narrador, é possível colocar em causa a própria ironia, que opera os ajustes entre a norma universal e a matéria da vida. $\mathrm{Ou}$, em outra fórmula reduzida: pôr em causa a acusação através da autocalúnia.

\section{O tribunal machadiano}

Em "A parasita azul", Camilo Seabra, filho de um proprietário de terras de Goiás, retorna da Europa ao Brasil após oito anos de ausência, período no qual estudou medicina em Paris. A melancolia do protagonista, como se vê ao longo de todo o conto, contrasta de maneira decisiva com um possível tom romântico que a narrativa poderia adquirir. Com efeito, o retorno a terras brasileiras é despido dos coloridos tons alegres da nação mãe: o que vem a primeiro plano, sem qualquer dúvida, é este exagerado sentimento de abatimento com que Camilo deixa os anos de ócio na Europa e é chamado à "vida real". A comparação com um prisioneiro que caminha em direção ao cadafalso compõe o tom um tanto ridículo com que é construído o dilema do jovem que é obrigado a abandonar os anos de farra em Paris. Mas, para além desta operação fundamental ao enredo, é possível derivar-lhe um outro sentido, ligado de maneira íntima ao funcionamento da forma realista em sua dupla relação com os elementos caros à realidade brasileira e com a ideologia burguesa que aqui desembarcava nas mãos dos filhos da elite, como é o caso do jovem Seabra.

Uma vontade substancialmente volúvel parece guiar o ânimo desta classe: é o que se percebe no batismo de Camilo, que recebeu o nome em homenagem a um poema de um naturalista francês de que seu pai tornara-se amigo. Da mesma maneira leve e irresponsável o fazendeiro "que nunca vira outra terra além da sua província natal" (MACHADO DE ASSIS, 2012, p.5) decide mandar seu filho para a França, terra de seu compadre, para aprender "medicina ou qualquer outra coisa em que se faça homem" (Idem, Ibidem). Frivolamente Camilo Seabra passa seus anos em Paris, em meio à 
diversão bancada pelas mesadas do pai. Sua felicidade acaba, no entanto, quando não mais consegue enrolar o patriarca, que exige seu retorno sob a ameaça de cortar-lhe o subsídio. O que chama a atenção nesta volta ao Brasil, no entanto, é que esta chamada à assunção da posição de proprietário não é de fato um convite à dura realidade, com a qual os anos de França contrastariam e que poderia representar um choque propício à formação de Camilo enquanto sujeito. Ao contrário, é de se notar que um tipo de ociosidade simplesmente é trocado por outro. Chegando à terra tosca de seu nascimento, Camilo nada faz além de ver-se envaidecido pelo título e pela vivência que obtivera na Europa. Porém quando o lisonjeio torna-se repetitivo, ele dá novamente lugar à sua "nostalgia do exílio". Seu tédio é desafiado somente quando o intriga a indiferença com que a jovem senhora Isabel o tratava: indiferença que invariavelmente mexeria com seus brios e o impulsionaria à nova meta que estabelece à sua vida: conquistar a senhorita.

Os detalhes deste empreendimento de conquista amorosa talvez não interessassem tanto se não trouxessem uma óbvia semelhança a recorrentes temas românticos: desde o pseudo-heroísmo que desperta o amor na jovem (a captura de uma flor pelo jovem Camilo, que cai da árvore e se machuca), à longa fidelidade a este amor impossível até, enfim, o desfecho feliz com o casamento. O arremate conciliador vai ao encontro da observação de Roberto Schwarz acerca da narrativa de juventude de Machado, afirmando haver nestes textos uma concentração de sentido em torno da família e da ordem, traço que desaparecerá em seus escritos posteriores (cf. SCHWARZ, 2000a, p.91). Contudo, antes de considerar, por exemplo, o desfecho de "A parasita azul" como um ponto fraco da prosa machadiana, talvez seja mais interessante vinculá-lo a dois planos de interesse para a análise que aqui se empreende: o primeiro diz respeito ao próprio movimento da trama. O final feliz de Camilo e Isabel, unidos em matrimônio, é absolutamente coerente com o resto da trajetória do protagonista. Seria possível dizer que mesmo os aspectos ridículos deste percurso encontram nexo com o tema de fundo da narrativa: os rumos do ócio proprietário.

Com efeito, Machado explora com maestria esta seara: desde o início, Camilo é representado como uma personagem sem qualquer substância subjetiva. Sua vaidade tem uma ligação profunda com o ócio que sua condição de filho de proprietário lhe proporciona. A representação de uma trajetória leviana, bem como do uso prosaico das formas ideológicas burguesas, coadunam com o fim harmônico do conto, que indica as azeitadas engrenagens da dominação proprietária. Dito de outra forma, seria possível afirmar que as estruturas materiais que condicionam a vivência de classe da elite brasileira conformam um quadro em que o ócio, a volubilidade e o uso interessado do verniz europeu estão afinados ao modo como se conciliavam ideologia liberal e produção escravista. Neste ponto adentra-se no segundo plano de coerência do conto de Machado. O manuseio totalmente utilitário e superficial de temas caros à ideologia burguesa europeia gera uma situação sui generis para a representação realista. Isto porque Machado de Assis, ao colocar-se em meio à difícil tradição romanesca brasileira, assume para si os desafios que dela derivam. Transferida para o Brasil a relação entre ideologia e real se complica, tal como afirma a consagrada tese de Schwarz: 
Neste contexto, portanto, as ideologias não descrevem sequer falsamente a realidade, e não gravitam segundo uma lei que lhes seja própria - por isso as chamamos de segundo grau. Sua regra é outra, diversa da que denominam; é da ordem do relevo social, em detrimento de sua intenção cognitiva e de sistema. Deriva sossegadamente do óbvio, sabido de todos - da inevitável 'superioridade' da Europa e liga-se ao momento expressivo, de autoestima e fantasia, que existe no favor.

(SCHWARZ, 2000a, pp.18-19, grifo meu)

A observação de Schwarz parece descrever com fidelidade a situação encontrada em "A parasita azul”. O teor ornamental que a ilustração europeia dá ao protagonista e membro da elite, sua insossa subjetivação, não somente descrevem de forma realista os quadros dominantes da sociedade brasileira. A reificação de "segundo grau" da ideologia potencializaria, com efeito, a possibilidade de um uso sem precedentes da ironia romanesca: a saber, o perspectivismo moral almejado pela alta literatura europeia por meio da calúnia do narrador parece ser deslocado de sua função na narrativa machadiana, que se agarra à autoironia ideológica que floresce em solo nacional como motivo íntimo de sua narrativa.

Este movimento coloca a prosa de Machado à beira de um deslocamento de fundamental importância e de graves consequências. Neste sentido, a maturidade do autor se confunde com o máximo questionamento da posição do narrador realista que se obtém com as obras narradas a partir da voz do membro da elite brasileira. Neste contexto, Dom Casmurro, romance de 1899, ganha um notável relevo: sua estrutura curiosa, algo entre a confissão e a calúnia, arranjo cuja especificidade reclama, mesmo que à revelia, a autocalúnia, propõe a resolução de um enigma que, à primeira vista, parece banal: trata-se de saber se o narrador tem ou não razão em sua acusação a Capitu. A questão, no entanto, complica-se na medida em que a acusação pode sofrer um refluxo para atingir o próprio narrador, colocando em causa o estatuto da narração: isto é, a questão da calúnia passa do plano de mero conteúdo de enredo - conteúdo corriqueiro e amiúde repisado - e migra para um questionamento ácido à própria forma do romance, já que é colocada em cheque a legitimidade de uma narrativa que se arma sobre a alta eloquência de Bentinho e se volta para o espúrio fim de justificar a obscuridade e o arbítrio senhoriais. Ou seja, há em Dom Casmurro o absoluto escancaramento da expectativa de condescendência do moralismo narrativo. O sujeito volúvel da classe proprietária, retratado enquanto objeto narrativo em "A parasita azul", ganha a voz nos romances de maturidade de Machado, expondo assim a arbitrariedade no uso da própria norma burguesa em contexto periférico e transferindo-a ao coração das questões formais.

Acerca deste trabalho em torno da ideologia, Roberto Schwarz afirma:

"É claro que a liberdade do trabalho, a igualdade perante a lei e, de modo geral, o universalismo eram ideologia na Europa também; mas lá correspondiam às aparências, encobrindo o essencial - a exploração do trabalho. Entre nós, as mesmas ideias seriam falsas num sentido diverso, por assim dizer, original".

(SCHWARZ, 2000a, p.12). 
Em outras palavras, se as reviravoltas políticas de 1848 puseram a nu o caráter ideológico das proposições universais burguesas, evidenciando seu entrincheiramento enquanto ideologia em favor de uma classe, aqui sua funcionalidade era outra: de certa forma, as próprias condições materiais a que estávamos sujeitos na posição de país agrário e exportador premiam a elite a uma resolução escancaradamente cínica de sua situação ideológica. Isto é, o cinismo com que Camilo Seabra manipula, enquanto protagonista, a ilustração superficial que adquirira em seus anos de farra na Europa vem agora, em todas as palavras de Bento, ao primeiro plano da forma narrativa adquirindo toda sua gravidade possível.

Com um mesmo gesto, portanto, Machado de Assis atinge o coração da representação realista exprimindo com a mais alta acuidade a realidade nacional. Em Dom Casmurro, não somente há a destruição metódica de todas as expectativas românticas gestadas na primeira metade do romance - na qual a vivacidade de Capitu ganha alto relevo, bem como o próprio entrecho amoroso entre membros de classes sociais diversas -, como se observa enquanto movimento preponderante a vitória do tom obscuro e autoritário de sua segunda metade sobre o resto da narrativa. A formaromance, bem como toda a ilustração do narrador, é usada, assim, como mero meio para um fim nefasto: justificar a acusação sumária a Capitu, fruto do pensamento oblíquo do narrador. Machado propõe assim uma solução inusitada para o impasse em torno da ironia romanesca: se esta advém da fricção entre a norma e o real, a narrativa de Bentinho, enquanto veste letrada do puro arbítrio, faz do próprio conluio do romance com a lei sua razão de existência. Se a miséria de Emma Bovary é o dado imediato que orquestra a aparição dos demais elementos substanciais em Madame Bovary, em Dom Casmurro este dado imediato é outro: ele não é o fruto ressecado, resultado do contato entre a norma e a vida, posto a nu através da autocalúnia; é antes a própria norma que se autoexpõe em sua operação caluniosa a cada passo da narrativa.

É gritante, portanto, a diferença entre a solução narrativa machadiana e aquela observada no romance europeu: e curiosamente, corroborando com este contraste, em seus momentos de maior debilidade dos ajustes irônicos é que a narrativa de Machado demonstra sua maior força. Um exemplo pode ser extraído de um período de bonança na amizade entre os dois casais, Bento e Capitu, Escobar e Sancha. Escobar diz a Bento que deseja revelar-lhe um projeto para os quatro no dia seguinte. Sancha, por sua vez, conta ao amigo qual seria o intento: uma viagem de todos à Europa. A partir desta confissão e do momento de intimidade e cumplicidade entre Sancha e Bento, o narrador abre espaço para que seu pensamento vaidoso e oblíquo veja neste gesto algo além do óbvio: 
A modéstia pedia então, como agora, que eu visse naquele gesto de Sancha uma sanção ao projeto do marido e um agradecimento. Assim devia ser, mas o fluido particular que me correu todo o corpo desviou de mim a conclusão que deixo escrita. Senti ainda os dedos de Sancha entre os meus, apertando uns aos outros. Foi um instante de vertigem e de pecado. Passou depressa no relógio do tempo; quando cheguei o relógio ao ouvido, trabalhavam só os minutos da virtude e da razão.

(MACHADO DE ASSIS, 1999, p.179, grifo meu).

Bento continua o devaneio a respeito da despedida de Sancha quando chega em casa, cogitando que, talvez, a afetuosidade que percebera na intenção da amiga nada mais fosse do que a empolgação com a viagem por vir. Os questionamentos morais de Bento, portanto, oscilam entre a rejeição da insinuação de Sancha em respeito a Escobar e a possibilidade de ter interpretado erroneamente a exaltação da mulher do amigo. Em nenhum momento passa por sua cabeça o óbvio: ele a desejara.

À beira de receber o julgamento do leitor, momento em que a fé na narrativa seria colocada em jogo, o narrador demonstra a consciência de sua ironia com um curto capítulo intitulado "Não faça isso, querida!", no qual diz: "A leitora, que é minha amiga e abriu este livro com o fim de descansar da cavatina de ontem para a valsa de hoje, quer fechá-lo às pressas, ao ver que beiramos um abismo. Não faça isso, querida; eu mudo de rumo" (Idem, p.181) ${ }^{4}$. Em um gesto brusco, Machado desloca o escopo narrativo da ação romanesca para os próprios fios irônicos que sustentam o romance, fazendo troça inclusive do próprio papel ideológico-moralista que o gênero assume em contexto burguês. Ou seja, no momento de debilidade do ajustamento irônico da forma - isto é, quando o efeito de ilusão do romance é ameaçado pelas demonstrações de inconfiabilidade do narrador - o gesto literário de Machado não é o de colocar em causa a posição narrativa. Pelo contrário, a interrupção do fluxo da trama e a consequente exposição da própria ironia põem à mostra o funcionamento íntimo do romance, colocando em relevo a instância narrativa como aquela que promove o ajustamento da forma ao particular. A arbitrariedade desta passagem infla de cinismo este gesto narrativo, operado da maneira mais moral possível. Machado posta, assim, no ponto de sustentação da ironia romanesca, o espelho que reflete a imagem do patriarca brasileiro tanto no âmbito da trama como da forma, fazendo com que a aplicação da norma - que, em última instância, pode ser rastreada até a acusação a Capitu - coincida com a vacuidade do arbítrio senhorial, formando um círculo narrativo irrefutavelmente oco.

O romance realista florescido em solo brasileiro traz consigo, portanto, esta potencialidade: o descolamento brutal entre a ideologia burguesa e as formas de vida a serem tocadas pela representação cria algo como um beco sem saída para o realismo. Qual seja: a realidade brasileira só pode verdadeiramente ser representada se, com isto, colocarem-se sob suspeita as próprias intenções íntimas do romance. Com efeito, as relações conflituosas que Machado mantém com o romantismo podem traçar sua origem das tentativas de resolução deste impasse: como dar tons locais à forma-romance sem que ela assuma um caráter nitidamente apologético? Como resposta a esta questão, é

4 A mudança de rumo a que se refere o narrador ganha ainda mais carga cínica se tiver em consideração que o evento que desvia o pensamento de Bento da cobiça à mulher alheia é a morte de Escobar. 
possível dizer que Machado alinha-se a mais alta literatura europeia reconhecendo que a fidedignidade à matéria brasileira exige outra estratégia para que se coloque em causa $o$ cinismo do narrador. Isto é, se por um lado a representação realista da sociedade patriarcal nunca seria possível sem que o desajuste ideológico burguês fosse posto em pauta pela literatura da segunda metade do século, pode-se também afirmar que, somente em um topos onde os conteúdos da ideologia burguesa encontram um manuseio inteiramente cínico pode-se ver o ponto de desconexão entre a lei e a vida.

Neste ponto, vincular-se-iam, portanto, uma hipótese de fundo histórico com outra de fundo formal: a "maturidade" da representação realista em Dom Casmurro só é possível a partir da decadência senhorial, marcada pelo declínio da escravidão enquanto instituição. Neste sentido, à ironia enquanto ajuste das abstrações universais à realidade, liberada de suas funções práticas, é possibilitado o giro em falso, que a faz ganhar ar de delírio, tornando-se dado imediato do romance e seu único princípio de sustentação. A saber: o desvario acusatório de Bento Santiago acaba por armar um falso tribunal repleto de ambiguidade, no qual cada palavra do narrador tende tanto à acusação de Capitu quanto à confissão dos crimes do patriarca. Na medida em que todas as palavras do narrador, erigidas com o fim de provar-lhe a inocência, são também provas de sua culpa, confissão e acusação se confundem na única categoria jurídica capaz de abarcar esta aporia: a autocalúnia. Como afirma Agamben:

Só há calúnia, com efeito, se o acusador estiver convencido da inocência do acusado, se acusar sem que haja uma culpa a demonstrar. No caso da autocalúnia, esta convicção torna-se ao mesmo tempo necessária e impossível. O acusado, na medida em que se autocalunia, sabe perfeitamente estar inocente, mas, na medida em que se acusa, sabe igualmente bem ser culpado de calúnia. (AGAMBEN, 2010, p.33)

Ao armar um falso tribunal narrativo, Casmurro, assumindo a palavra que acusa e lança dúvida, faz troça da posição de narrador e, deste modo, se impregna da máxima consciência acerca da íntima relação mantida entre aquele que narra e aquele que julga. A autocalúnia abrigaria, portanto, também neste caso as aporéticas estratégias da representação realista ante sua complicada relação com a ideologia: no entanto, ao contrário do ataque à posição do narrador, no caso de Machado há a possibilidade de o máximo de cinismo formal coincidir com o máximo de realismo, o que acabaria por deslocar a acusação do narrador ao próprio romance enquanto forma. Isto é: a pergunta erigida pelo romance de Machado não seria "qual a autenticidade e o lugar da voz que narra?", mas "é possível um romance sem ironia?".

De certo não se pode arrogar esta estratégia a Bento, mas talvez ao narrador por trás do narrador, que, à espera do gesto crítico a posteriori, acaba jogando a calúnia contra si, expondo assim, sem nenhuma reserva, o ponto em que a norma, absolutamente reificada, pode perder o ponto de contato com o real, o que coloca em suspensão sua vigência. Haveria, portanto, uma outra instância que, por trás deste primeiro plano narrativo, aguardaria o gesto crítico que levasse a cabo precisamente o que propõe Schwarz (1997, p.10): isto é, inverter o polo de acusação de Capitu para o narrador. Com esta reversão do polo acusatório, não só o tribunal de Bento é posto em 
cheque. O movimento fundamental, que engatilha o grande potencial estético-político da obra machadiana, parece depender do gesto crítico que pode suspeitar dos termos de acusação da narrativa. Neste sentido, enquanto o romance europeu se vê às voltas com uma impossibilidade de sair do círculo formado pela autocalúnia, o giro em falso da acusação de Bentinho parece entregar nas mãos da crítica um objeto fossilizado: a própria ironia romanesca. Assim, se o romance realista luta e se arma de mecanismos formais para eliminar o ruído da ironia, a narrativa machadiana é só ruído. Mas, neste gesto paradoxal, ela parece oferecer à vista a ideologia enquanto objeto reificado e desconectado do real: o fóssil que, da melhor maneira dialética, guarda em si a chave de desvendamento do passado e do futuro.

\section{Referências bibliográficas}

AGAMBEN, Giorgio. “K.” In: Nudez. Lisboa: Relógio D’Água Editores, 2010.

AUERBACH, Erich. "Na Mansão de La Mole” In: Mimesis: a representação da realidade na literatura ocidental. São Paulo: Perspectiva, 2007.

JAMES, Henry. "The Figure in the Carpet”. In: Selected Tales. London: Penguin Books, 2001.

KAFKA, Franz. O castelo. São Paulo: Companhia das Letras, 2000. . O processo. São Paulo: Companhia das Letras, 2005.

LUKÁCS, Georg. A teoria do romance: um ensaio histórico-filosófico sobre as formas da grande épica. São Paulo: Duas Cidades; Ed. 34, 2000.

O romance histórico. São Paulo: Boitempo, 2011.

MACHADO DE ASSIS, Joaquim Maria. Dom Casmurro. 5ª ed. São Paulo: FTD, 1999. . “A parasita azul” In: Histórias da meia-noite. Rio de

Janeiro, Editora Garnier, 1873. Disponível em <

http://machado.mec.gov.br/images/stories/pdf/contos/macn002.pdf $>$. Acesso em 18 jun. 2012.

São Paulo: Global, 1984.

MARX, Karl. O 18 Brumário e Cartas a Kugelmann. $7^{\mathrm{a}}$ ed. Rio de Janeiro: Paz e Terra, 1997.

SCHWARZ, Roberto. Ao vencedor as batatas: forma literária e processo social nos inícios do romance brasileiro. São Paulo: Duas Cidades; Ed. 34, 2000a.

Duas meninas. São Paulo: Companhia das Letras, 1997.

Um mestre na periferia do capitalismo: Machado de Assis. São

Paulo: Duas Cidades; Ed. 34, 2000 b. 